Available online at: http://proceeding.rsfpress.com/index.php/ic-smart/index

Proceeding on International Conference of Science Management Art Research Technology

(IC-SMART)

Volume 1 Number 1 (2020): 49-57

\title{
The Influence of Role Conflict, Role Ambiguity and Role Overload on Auditor Performance (Empirical Study at the BPK Representative Office of the Republic of Indonesia in Maluku Province)
}

\author{
Yuyun Yuniarti Layn, Rita J.D. Atarwaman \\ Pattimura University \\ E-mail address yuniarti112@gmail.com E-mail address rita.atarwaman72@gmail.com
}

\begin{abstract}
This research is motivated by a decrease in auditor performance caused by problems that occur in the auditors' work environment. This study aims to determine the effect of role conflict, role ambiguity, and role overload on auditor performance. The research method used is descriptive quantitative. The population in this study were the auditors of BPK RI Representatives of Maluku Province, which also became the sample. Data collection techniques through distributing questionnaires to 50 respondents auditors of BPK RI Representatives of Maluku. Data analysis techniques using multiple regression. The test results show that role conflict has a negative and significant effect on the performance of the auditors, which shows that the more role conflicts the auditor gets, the lower his performance. Role ambiguity variable has no effect because role ambiguity can make someone uncomfortable at work, which in turn will affect the auditor's performance. Meanwhile, the role overload variable has no effect, indicating that excessive work pressure with limited time will make the auditor's performance not optimal in his work.
\end{abstract}

Keywords: Role Conflict, Role Ambiguity, Role Overload, and Auditor Performance.

This is an open access article under the $\mathrm{CC}-\mathrm{BY}-\mathrm{NC}$ license

\section{INTRODUCTION}

Supervision is one of the management functions carried out in order to achieve objectives to ensure that the implementation of activities is in accordance with the predetermined plan. Supervision needs to be carried out optimally and is beneficial for the auditee (organization, government, and state) in realizing objectives or programs in an effective, efficient, and economical manner.

The auditor aims to assist all parts of the company in order to carry out their functions effectively and efficiently. Auditor performance is the result achieved by the auditor in carrying out his duties based on the responsibilities given and is one of the benchmarks used to determine whether a job is done properly or otherwise. 
Proceeding on International Conference of Science Management Art Research Technology (IC-SMART), Vol. 1 (1), 49-57

The Influence of Role Conflict, Role Ambiguity and Role Overload on Auditor Performance (Empirical Study at the BPK Representative Office of the Republic of Indonesia in Maluku Province)

YuyunYuniarti Layn, Rita J.D. Atarwaman

In Maluku, there was the Indonesian Financial Audit Board (BPK) Representative of Maluku Province regarding questionable audit results because in the audit report on the financial reports of the West SeramDistrict Government for the 2014 fiscal year. Where the Treasurer of the Regional People's Representative Council (DPRD) is suspected of committing acts of corruption related to funds of Rp. 1.7 billion based on the results of the BPK RI audit for the 2012-2013 fiscal year, this was conveyed by Nurlete, a member of the Islamic Youth Movement (GPI).

These cases occur that there are still auditors who make mistakes in carrying out their duties so that it makes a decrease in the performance of these auditors, the impact must have an effect on the performance of the agency where they work.

\section{LITERATURE REVIEW}

\section{II.1. Role Theory}

Kahn (1964) role theory is an emphasis on the character of the individual as a social actor who studies behavior in accordance with the position occupied in society. The role is a central concept of role theory (Shaw \&Constanzo 1970). Thus the study of role theory cannot be separated from the definition of roles and various terms of behavior in it.

\section{II.2. Role Conflict}

Role conflict is a conflict arising from the mechanization of bureaucratic organizational control that is not in accordance with norms, ethics, and professional independence.

This condition usually occurs because there are two different commands that are received simultaneously and the execution of one command alone will result in another command. Role conflict is a conflict faced by a person if two or more sets of expectations contradict each other (FX. Suwarto, 1999: 237).

From some of the definitions above, it can be concluded that role conflict is a situation where an individual experiences a mismatch between orders or requests given a commitment from a role.

\section{II.3. Role Ambiguity}

Robbins and Judge (2009: 499) state that role ambiguity is behavior that is determined to employees is unclear. Role ambiguity is the lack of information held and the absence of clear direction and policies, uncertainty about authority, obligations, and other relationships., and the uncertainty of sanctions and rewards for behavior (ZaenalFanani et al., 2007: 24. As in role conflict, role ambiguity tends to cause tension and conformity (J.winardi 2007: 416).

\section{II.4. Role Overload}

Role overload is a condition where a person has too much work to do at a certain time (Almer and Kaplan, 2002 in Rapina 2008). The absence of a good planning for manpower requirements can make auditors experience excess roles. Based on this explanation, it can be concluded that role overload, namely role overload that occurs when an auditor has too much work to do under the pressure of a very tight schedule.

\section{II.5. Auditor Performance}

Mulyadi (2002), auditor performance is a condition in which a public accountant carries out an objective examination of the financial statements of a company or other organization with the aim of determining whether the financial statements present fairly in accordance with generally accepted accounting principles. All material matters, financial position, and results of operations of the company, and in conducting audits, the auditor must comply with the Indonesian public accountant's code of ethics and auditing standards, which are now known as ISA-based audits.

Based on the description above, the research hypothesis is formulated: 
H1: Role Conflict has a negative effect on auditor performance

$\mathrm{H} 2$ : Role ambiguity has a negative effect on auditor performance

H3: Role overload has a negative effect on auditor performance

\section{RESEARCH METHODOLOGY}

\section{III.1. Population and Sample Research}

The population in this study were all government auditors who work at the Maluku Provincial BPK Representative Office based in the capital city of Maluku Province, Ambon. In this study, we are using a census sample because all members of the population are used as the sample.

\section{III.1. 3.2. Operational Definition and Variable Measurement.}

The operational definition of variables is how to determine and measure these variables in the field by formulating them briefly and clearly, and not causing various interpretations.

The questions or statements in the respective questionnaire in this study are measured using a Likert scale to determine the attitudes, opinions, perceptions of a person, or group of people about social phenomena.

The answers to the questionnaire are quantitative in nature so that the answers are scored using a 5 (five) point Likert scale. Namely: The value $1=$ never, $2=$ almost never, $3=$ sometimes, $4=$ often, 5 = always.

This study consists of two variables, independent variables (Role Conflict, RoleAmbiguity, Role Overload) and Dependent Variables (Performance Auditor). Based on literature review and previous research, the operational variable approach for each variable in this study is as follows:

\section{Role Conflict}

Role conflicts arise as a result of organizational bureaucratic control mechanisms that are not in accordance with norms, rules, ethics, and professional independence. This condition usually occurs because there are two different orders that are received simultaneously and the application of just one command will result in the neglect of the other (Zaenal Fanani et al., 2008)

\section{Role ambiguity}

role ambiguity is the lack of information held and the absence of a clear policy direction, uncertainty about authority, obligations, and relationships with others, and uncertainty of sanctions and rewards for behavior (ZaenalFanani et al., 2008: 24).

\section{Role Overload}

Role overload is a situation where a person has too much work to do at any given time (Almer and Kaplan, 2002 in Rapina 2008). This research variable was measured using an instrument developed by ZaenalFanani et al. (2008).

Auditor Performance

Performance is a form of one's success in achieving certain roles or targets that come from one's own actions. A person's performance is said to be good if the individual's work can exceed a 
predetermined role or target (Reza Surya, 2004: 35). The auditor performance variable in this study was measured using an instrument developed by ZaenalFanani et al. (2008). This variable is measured using a 5-point Likert scale, from very less successful than others (1), less successful than others (2), as successful as others (3), more successful with others (4), very more successful than others (5).

Methods of data analysis using descriptive analysis, reliability test, validity test, and classical assumption

Testing the hypothesis in this study using multiple linear regression analysis to examine the influence between auditor performance as the dependent variable, the dependent variable, and the independent variable. The regression equation can be written as follows:

$\mathrm{Y}=\mathrm{a}-\mathrm{b} 1 \mathrm{X} 1-\mathrm{b} 2 \mathrm{X} 2-\mathrm{b} 3 \mathrm{X} 3+\mathrm{e}$

Where :

$\mathrm{Y}=$ auditor performance

$\mathrm{a}=$ constant

$\mathrm{b}=$ regression efficiency

$\mathrm{X} 1=$ role conflict

$\mathrm{X} 2=$ role ambiguity

$\mathrm{X} 3=$ role overload

$\mathrm{e}=$ error

\section{Hypothesis testing}

Partial Test (t-test)

The t-test is used to determine whether the independent variable (role conflict, role ambiguity, role overload) individually or partially affects the dependent variable (auditor performance). If the probability t value $<0.05$, then Ha is rejected. (Ghozali, 2013).

\section{Efficiency of Determinants}

The efficiency of determination is an overview stating how well the sample regression lines match the data. The efficiency of determination to measure the proportion of the variable in the dependent variable described by regression. $\mathrm{R} 2$ value ranges from 0 to 1 . If $\mathrm{R} 2=0$ means there is no relationship between the independent variable and the dependent variable, whereas if $\mathrm{R} 2=1$ means a perfect relationship. For regressions with more than two independent variables, adjusted R2 is used as the determinant factor.

\section{FINDING AND DISCUSSION}

In this study, the analysis method used is multiple regression analysis. To determine the regression equation can be seen in the table below: 


\section{Coefficients}

Table 1. Multiple Regression Test

\begin{tabular}{|c|c|c|c|c|c|c|}
\hline \multirow{2}{*}{\multicolumn{2}{|c|}{ Model }} & \multicolumn{2}{|c|}{$\begin{array}{l}\text { Unstandardized } \\
\text { Coefficients }\end{array}$} & \multirow{2}{*}{$\begin{array}{c}\text { Standardized } \\
\text { Coefficients } \\
\text { Beta }\end{array}$} & \multirow[b]{2}{*}{$\mathrm{T}$} & \multirow[b]{2}{*}{ Sig. } \\
\hline & & B & $\begin{array}{l}\text { Std. } \\
\text { Error }\end{array}$ & & & \\
\hline \multirow[t]{4}{*}{1} & (Constant) & 34.000 & 2.101 & & 15.921 & .000 \\
\hline & TRC & -.254 & .058 & -.450 & -3.201 & .001 \\
\hline & TRA & .059 & .064 & .078 & .525 & .370 \\
\hline & TRO & -.143 & .166 & -.062 & -1.106 & .131 \\
\hline
\end{tabular}

a. Dependent Variable: TPA

Based on table 9 above, it is known that the coefficient value of the regression equation from the output shows the regression equation model:

$\mathrm{Y}=\alpha-\beta 1 X 1+X 2-\beta 3 X 3+\mathrm{e}$

$\mathrm{Y}=34,000-0.254 \mathrm{X} 1+0.059 \mathrm{X} 2-0.143 \mathrm{X} 3+\mathrm{e}$

Information:

$\mathrm{Y}=$ Auditor Performance

$\mathrm{e}=$ Standard Error

$\alpha=$ Constant

$X 1=$ Role Conflict

$X 2=$ Role Ambiguity

$X 3$ = Role Overload

$\beta 1=$ Role Conflict variable regression coefficient

$\beta 2=$ Role ambiguity variable regression coefficient

$\beta 3=$ Role Overload variable regression coefficient

The results of the regression equation, a constant value of 34,000, means that Role Conflict (X1), Role Ambiguity (X2), and Role Overload (X3) are considered constant, so auditor performance is constant at 34,000.

The regression coefficient for the Role Conflict variable (X1) is -0.254 , meaning that if other variables have a fixed value and Role Conflict (X1) has increased by $1 \%$, then the auditor's performance $(\mathrm{Y})$ will increase by -0.254 .

The regression coefficient for the variable Role Ambiguity (X2) is 0.059 , meaning that if the other variables are fixed in value, and Role Ambiguity (X2) has increased by $1 \%$, then the auditor's performance (Y) will increase by 0.059 . 
The regression coefficient of Role Overload (X3) is -0.143 , which means that if other variables have a fixed value and Role Overload has increased by $1 \%$, then the auditor's performance $(\mathrm{Y})$ will increase by -0.143 .

Test the coefficient of determination (R2)

The coefficient of determination test results are used to measure how much the model's ability to explain the variation in the independent variable

Table 2

Test the coefficient of determination (R2)

Model Summary

\begin{tabular}{|c|c|c|c|c|}
\hline Model & $\mathrm{R}$ & $\begin{array}{c}\mathrm{R} \\
\text { Square }\end{array}$ & $\begin{array}{c}\text { Adjusted R } \\
\text { Square }\end{array}$ & Std. Error of the Estimate \\
\hline 1 & $.453^{\mathrm{a}}$ & .201 & .154 & 1.801 \\
\hline
\end{tabular}

a. Predictors: (Constant), TRO, TRC, TRA

Based on table 10, the test results of the coefficient of determination above show an Adjusted $\mathrm{R}$ Square value of 0.154 or $15 \%$. This value shows that the auditor's performance variable can be explained by $15 \%$ by the independent variables Role Conflict, Role Ambiguity, and Role Overload. While the remaining $85 \%$ is influenced by other variables outside the variables studied, such as intellectual intelligence, independence, organizational commitment, experience, autonomy, professionalism and ethical practice.

Hypothesis testing

t-test

The $t$ statistical test is useful for testing the effect of each independent variable partially on the dependent variable. To see that there is no effect of each independent variable partially on the dependent variable, it can be seen at the 0.05 significance level

Table 3t-test

\section{Coefficients}

\begin{tabular}{|c|c|c|c|c|c|c|}
\hline \multirow{2}{*}{\multicolumn{2}{|c|}{ Model }} & \multicolumn{2}{|c|}{$\begin{array}{l}\text { Unstandardized } \\
\text { Coefficients }\end{array}$} & \multirow{2}{*}{$\begin{array}{c}\text { Standardized } \\
\text { Coefficients } \\
\text { Beta }\end{array}$} & \multirow[b]{2}{*}{$\mathrm{T}$} & \multirow[b]{2}{*}{ Sig. } \\
\hline & & B & $\begin{array}{l}\text { Std. } \\
\text { Error }\end{array}$ & & & \\
\hline \multirow[t]{4}{*}{1} & (Constant) & 34.000 & 2.101 & & 15.921 & .000 \\
\hline & TRC & -.254 & .058 & -.450 & -3.201 & .001 \\
\hline & TRA & .059 & .064 & .078 & .525 & .370 \\
\hline & TRO & -.143 & .166 & -.062 & -1.106 & .131 \\
\hline
\end{tabular}

a. Dependent Variable: TPA 
source: primary data processed

Based on the table above, it can be seen the level of significance of each independent variable. Of the three independent variables, the two variables included in the regression model produced a significant $p$ value $>0.05$, and one variable included in the regression model resulted in a significance value of $\mathrm{P}$-value $<0.05$.

For the first independent variable, namely Role Conflict, then t-count $=-3.201$ is greater than $t$ table 2.0243, so partially role conflict has a negative effect on auditor performance. Thus also obtained a significant value of $0.001<0.05$, which has a significant effect. This indicates that $\mathrm{H} 1$ is accepted.

The research is in line withZaenalFanani (2008), which states that Role Conflict has a negative and significant effect on auditor performance. This proves that the more role conflicts the auditor gets, the lower the performance, and if the role conflict decreases, the higher the auditor's performance.

The results of this test show that the auditors cannot do their job properly because the auditors experience a mismatch between the orders or requests given. This condition occurs because of two different orders. This results in the resulting auditors' performance being ineffective and inefficient. The higher the level of role conflict that occurs by the auditor, the lower the level of the auditor's performance. Some auditors will experience stress levels due to role conflicts in the work so that the work done will be ineffective and efficient. In addition, junior auditors who do not have much work experience often experience role conflicts because there is a lot of pressure exerted by senior auditors as well as the personal work they handle themselves which makes auditors experience stress, become dissatisfied, and become less effective, this results in lower auditor performance. This research is in line with research conducted by Agustina (2009) and Putra (2012), which states that role conflict has a negative and significant effect on auditor performance.

For the second independent variable, namely Role Ambiguity, the value of t-count $=0.525<\mathrm{t}$-table 2.0243 is obtained. This means that partially Role Ambiguity has no effect on auditor performance. Likewise, the significant results show a value of $0.370>0.05$, which means there is no significant effect. The conclusion is that Ho is accepted and $\mathrm{H} 1$ is rejected.

The occurrence of Role Ambiguity due to insufficient information and uncertainty of clear directions and policies. Work experience can be a solution to reduce this Role Ambiguity. It is proven that $60 \%$ of the 43 auditors of BPK RI representatives of Maluku Province have more than six years of work experience, this has made the auditors have sufficient information to complete their work, also from the existence of rules and authorities. What is clear from the BPK RI regarding sanctions and rewards for auditor violations has triggered the reduction of unclear roles in the BPK RI Representatives of Maluku Province.

The results of this study are not in line with research conducted by Elizabeth Hanna (2013), which states that role ambiguity has a negative and significant effect on auditor performance. Fitriany (2011) and ZaenalFanani (2008) which show that role ambiguity has a negative effect on auditor performance. The results of this study are in line with research conducted by Dyah (2002), which shows that role ambiguity is not related to auditor performance.

For the third independent variable, namely Role Overload, the value of count $=-1.162<\mathrm{t}$-table 2.0243. This means that partially Role Overload does not affect the performance of auditors. Likewise, the significance value shows a value of $0.131>0.05$, which means there is no significant effect. The conclusion is that Ho is accepted and $\mathrm{H} 1$ is rejected. 
Role Overload occurs when auditors have too much work to do at a certain time, and the absence of a proper workforce planning can make auditors experience excess roles, especially during the Busy Season. In some cases, there were excess due to lack of the number of auditors, which resulted in the auditors working extra to complete tasks under a very tight schedule. In a BPK office, the number of auditors who are able to improve the performance of auditors is proven by the large number of auditors so that they are able to guarantee their respective duties and that there is no overload or overload.

The results of this study contradict the research of I Gede Bandar Wira Putra (2012) and LidyaAgustina (2009) which shows that Role Overload affects auditor performance.

On the other hand, the results of this study support the research of RhenyAfrianaHanif (2013) which shows that Role Overload has no effect on auditor performance. LidyaAgustina (2009) states that excess influence has a negative and significant effect on auditor performance.

\section{CONCLUSION AND FURTHER RESEARCH}

This study aims to determine the factors that affect the performance of auditors, namely Role Conflict, Role Ambiguity, and Role Overload at the BPK RI Auditor Representatives of Maluku Province. Based on the research results, the following conclusions can be drawn:

1. Role Conflict has a significant negative effect on auditor performance. This proves that the more role conflicts the auditor get, the lower the performance is. The results of this test indicate that the auditors cannot do their job properly because the auditors experience a mismatch between the orders or requests given.

2. Role ambiguity has no effect on auditor performance, meaning that role ambiguity can make someone uncomfortable at work, which will ultimately affect auditor performance, but this does not happen to the BPK RI Auditor Representative of Maluku Province due to experience in working so that with sufficient experience and information auditors can complete their work.

3. Role Overload does not affect the performance of auditors, which means that the auditors of BPK RI Representatives of Maluku Province have sufficient experience in working so that with the experience the auditor has, the auditors are able to carry out their duties properly.

\section{REFERENCES}

Dyah Sih Rahayu, 2002: Antecedents and Consequences of Role Stress on the Independent Auditor; Indonesian Journal of Accounting Research; Vol 5, No.2

Ghozali, Imam, 2013: Multivariate Analysis Application With IBM SPSS 21 Program, Semarang; Diponegoro University Publishing Agency.

Hanna, Elizabeth and Friska Firnanti, 2013. FactorsAffecting Auditor Performance. Journal of Business and Accounting; Vol. 15 No. 1; 13-28

Handoko B.L, 2019; The Effect of Audit Technique, Auditor Skill and Role of Whistleblower on Effectiveness of Government Audit; International Journal of Innovative Technology and Exploring Engineering. 9 (2), 1525-1530

Lidya Agustina, 2009; The Influence of Role Conflict, Role Ambiguity and Role Overload on Employee Satisfaction and Auditor Performance; Accounting journal;Vol. 1 No. 1. 
Kompiang Martina Dinata Putri, 2013: The Influence of the Independence of Professionalism and Professional Ethics on Auditor Performance in KAP in Bali; E-Journal Accounting; Vol 4 No. 1.

Putra, I Gede Bandar Wira and Dodik Ariyanto, 2012: The Influence of Independence, Professionalism, Audit Structure and Role Stress on the Performance of the BPK RI Representatives of the Province of Bali; Accounting journal; 1-18.

Rapina, 2008; Relationship between Supervision, Role Stress and Performance and the desire to move to KAP in Jakarta; Scientific Journal of Accounting; Vol. 7 No. 1.

Rheni Afriana Hanif, 2013: The Effect of Audit Structure, Role Conflict and Role Ambiguity on Auditor Performance; Journal of Economics Vol 21 No. 3.

I Gede Bandar Wira Putra, Dodik Aryanto, 2012; The Influence of Independence, Professionalism, Audit Structure, and Role Stress on the Performance of BPK RI Auditor Representatives of Bali Province; E Journal Accounting; Vol 1 No. 1.

Jemmy Esrom Serang, Wiwik Utami, 2020; The Effect of Professionalism, Leadership Style, Organizational Commitment and Locus of Control on Auditor Performance (Study at a Public Accounting Firm in Jakarta); International Journal Of Advanced in Scientific Research and Engineering.

Meilda Wiguna, Khoirul Aswar, Eka Hariyani, 2020; Auditor Performance in Public Accounting Firm in Riau: The Moderating Effect of Emotional Quotient; European Journal of Business and Management Research.

Yilmaz Akgunduz, 2015; The Influence of Self-Esteem and Role Strees on Job Performance in Hotel Business; International Journal of Contemporary Hospitality Management.

Zainal Fanani, Rheni A Hanif, Bambang Subroto, 2008: The Effect of Audit Structure, Role Conflict and Role Ambiguity on Auditor Performance; JAKI Vol 5 No. 2 